\title{
Malaysia technical and vocational education and training (TVET) history and transformation
}

\begin{abstract}
Malaysia's apprenticeship is one of the government's premier efforts in providing skilled labor to meet the needs of industry in Malaysia. According to statistics released by the Economic Planning Unit (EPU) of the Prime Minister's Department of Malaysia, in 2018 Malaysia had 11.6 million workers comprising 51.4 percent in the services sector, 42.6 percent in the manufacturing sector, and 12 percent in the agricultural sector. With 3.3 percent of unemployment rate, this scenario makes Malaysia a highly competitive country in the 18th world because almost half of its people work. This also puts the country with the lowest unemployment rate in the world. However, the job training sector continues to be a key focus of the government to accelerate technical and vocational education through apprenticeship training provided at various skill institutions in Malaysia.
\end{abstract}

Volume 5 Issue 5 - 2020

\author{
Ridzwan Che Rus,' Ruhizan Mohamad Yasin ${ }^{2}$ \\ 'Faculty of Technical and Vocational, Universiti Pendidikan Sultan \\ Idris, Malaysia \\ ${ }^{2}$ Faculty of Education, Universiti Kebangsaan Malaysia, Malaysia
}

Correspondence: Ridzwan Che Rus, Faculty of Technical and Vocational, Universiti Pendidikan Sultan Idris, Malaysia,

Email ridzwn@ftr.upsi.edu.my

Received: October 30, 2019 | Published: October 30, 2020

Keywords: Malaysia, workers, training, vocational education, apprenticeship

\section{Introduction}

Finch and Crunkilton ${ }^{1}$ in a book that discusses curriculum development in Technical and Vocational Education (PTV) states that the Technical and Vocational Education System (PTV) is designed to provide students with the potential to excel. Therefore, the system should enable workers born of the system to have high levels of skill and employability. In addition, PTV also provides skills in specific areas of industry, agriculture and trade. ${ }^{2}$ Unlike academic education, PTV is an investment venture that builds knowledgeable and skilled human capital for the country's needs to achieve its mission and vision. According to the statistics presented by Ahmad Tajudin $\mathrm{Jab}^{3}$ on PTV transformation in Malaysia in 2006, only 10 per cent of students chose to follow vocational and skills flow compared to the Netherlands with almost 70 per cent of students choosing vocational flow, followed by Australia by 62 percent and Germany by 59 percent. This scenario is that in 2010, Malaysia had only 28 percent of highly skilled workers ${ }^{3-5}$ compared to other countries such as Singapore in 2008 with 48 percent of skilled and professional workers. This situation, if not curtailed, will cause the country's efforts to achieve the vision of 2020 will stall.

To address the problem, enrollment of students into vocational skills streams should be increased to 134,000 students compared to 67,000 currently. In order to achieve that desire an understanding of the phenomena that shape students with skills should be studied. The understanding formed will assist the government's efforts to change the perception of parents and students who underestimate the vocational flow. In developed countries, technical education and vocational training are among the top choices for students as they provide good career prospects. On the contrary, in our country, it is seen as the last option because of the limited perception of career prospects. ${ }^{6}$ Vocational pathway and skills in technical schools will be rebranded to provide more opportunities for students to develop technical skills and raise awareness regarding Technical Education and Vocational Training (PTLV). ${ }^{4}$ The re-branding of the stream is the government's sincere desire to ensure successful implementation of funding in this area. It is also hoped that this will change the perception of parents in this area and make it a community choice.
Society should be defined by the various PTLV terms used to avoid misinterpretation of the term. Various terms used to refer to the meaning and purpose of Technical and Vocational Education (PTV) are used today in many countries with similar meanings, such as Technical Education and Vocational Training (PTLV), Technical and Vocational Education (PTV), or Technical Education and Training and Vocational (PLTV) and Technical and Career Education (PTK) currently in use in America. Although there are variations in the name and meaning of the PTV education system, it is not a major issue that drives the education system as each of these definitions has a philosophy behind it.

Miller $^{7}$ identifies 3 major philosophies that support vocational education:

Essentialism: Training teachers are the main focus of the training system where expertise is an important element and is gained through the skills development process. This process involves the repetition, repetition, and preparation of behavioral changes.

Existentialism: Coaches are the main focus of the process where selfdevelopment is key to the success of the learning process.

Pragmatism: Coaches and teachers are an integral part of the training system. Reality or real world is emphasized contextual experiences are fundamental to the process involved.

It is clear here that coaches, teachers and training systems are an important component of the vocational training system. In Malaysia, in the Education Act of Malaysia ${ }^{8}$ in section 7 of section 35 Section 2, for the purposes of subsection (1), uses the term technical education to represent technical and vocational education and training. According to this Act, engineering education includes the provision of:

\section{a. Skills training;}

b. Special training related to specific occupations;

c. Training to improve existing skills

d. Any other technical or vocational training approved by the Minister. 
According to UNESCO in a paper entitled "Revised Recommendation concerning Technical and Vocational Education" PTV can be defined as:

"Technical and vocational education is used as a comprehensive term referring to those aspects of the educational process involving, in addition to general education, the study of technologies and related sciences, and the acquisition of practical skills, attitudes, understanding and knowledge relating to occupations in various sectors of economic and social life." To provide a clearer picture of UNESCO, we further extend our definition of PTV by listing four important aspects in addition to the above definitions:

a. Part of general education.

b. Provided in preparation for effective participation in the world of work.

c. Some aspects of lifelong education and responsible citizen preparation.

d. As a tool to promote a sustainable development environment.

This is further reinforced by Bennet ${ }^{2}$ who has divided PTV into two forms:

1. Formal education system.

2. Education and informal training or on-job training and onthe-job training.

Based on the analysis given by Bennet ${ }^{2}$ above, it is clear that the established model should have two types of formal education-based learning systems in vocational training educational institutions as well as industry experience education. Efforts towards developing an apprenticeship model should include the theory of experiential learning founded by John Dewey, ${ }^{9}$ which is about effective learning if students are engaged in their own learning activities that involve practical and interactive activities. This is in accordance with the definitions given above. Apprenticeship is a form of training to gain knowledge and skills in the field of apprenticeship. According to City and Guilds apprenticeship is a training that involves two modes of learning-learning in accredited training centre's as well as industrial learning. This will be achieved through an effective learning process. According to Victor learning is the act of acquiring knowledge or skills through observation. Moore argues that learning refers to the construction of activity systems, reorganizations or knowledge transformations. The situation of this activity system can be referred to an individual, a group of people or a community of work people.

Tyler states that learning experience refers to the two-way interaction between the coach and the external environment in which the coach responds. According to him, learning takes place through the active behaviour of the coach by doing what is learned rather than what the teacher does. However, there is another opinion by John Dewey that states that effective learning occurs, if apprentices are involved, doing their own learning activities that involves practical activities and interactions. ${ }^{9}$ Kolb $^{9}$ adds that learning is a process by which knowledge is constructed through the process of experience transformation. Thus, apprenticeships are a learning exercise for gaining knowledge and skills through observation, interaction and experience doing such things by apprentices. There are various technical and vocational training systems in Malaysia that focus on the training of the apprenticeships:
A. Certificate of Skills Malaysia (MCMC) issued by the Department of Skills Development (JPK).

B. National Modular Certificate (SMK) issued by the Community College Management Department (JPKK).

C. The German Vocational Education System implemented at the German Institute of Germany (GMI).

D. The Japanese Vocational Education System implemented at the Technical Institute of Malaysia Japan (JMTI).

E. The French Vocational Education System implemented at the French Institute of Malaysia (MFI).

F. Certificate of Construction Academy of Malaysia issued by the Construction Industry Development Board (CIDB).

G. Certificate issued by the Energy Commission.

H. Malaysian Agricultural Certificate and Diploma issued by the National Agriculture Training Council (NATC).

I. Certificate issued by the Malaysia Timber Industry Board (MTIB). ${ }^{10}$

\section{Conclusion}

Due to the large number of educational and training institutions, the major problem facing the Malaysian government in addressing post-secondary education and training is how to coordinate and direct the institution towards common aspirations by 2030 If the diversity of these existing systems is not well controlled there is a possibility that employers may not recognize the technical and vocational education apprenticeship issued by the participating institutions. This is because the workers being released do not meet the level of skill required by the industry.

\section{Acknowledgments}

None.

\section{Funding}

None.

\section{Conflicts of interest}

Authors declare that there is no conflict of interest.

\section{References}

1. Finch CR, JR Crunkilton. Curriculum Development in Career and Technical Education Ed. Boston: Allyn and Bacon; 1999.

2. Bennet. Recent Trends in the Organization of Vocational Education and Training: An International Comparative Review With Special Emphasis on Issues of Decentralization. De-Concentration and Privatization. 2003.

3. Ahmad Tajudin Jab. Transformation of Voctech Education in 10th Malaysia Plan. Jabatan Pendidikan Teknikal, Kementerian Pelajaran Malaysia. 2009

4. Malaysia. Rancangan Malaysia ke-10. K. Malaysia: Kuala Lumpur, Percetakan Nasional; 2010.

5. Mohd Gazali Abas. Isu-isu semasa Dalam Pendidikan Latihan Teknikal dan Vokasional di Malaysia. JPM. Unit Perancang Ekonomi. Kuala Lumpur; 2011. 
6. Malaysia. Wawasan Kemakmuran Bersama (Shared Properity Vision). Kuala Lumpur, Percetakan Nasional. 2019.

7. Miller MD. Principles and a philosophy for vocational education. Columbus OH. The Ohio State University. 1985.

8. Malaysia. Akta Pendidikan Kebangsaan. K. Malaysia. Kuala Lumpur, Percetakan Nasional. 2006.
9. Kolb AY, Kolb AD. Learning Styles and Learning Spaces: Enhancing Experiential Learning in Higher Education. Academy of Management Learning \& Education. 2005;4(2):193-212.

10. Kirkpatrick DL, JD Kirkpatrick. Evaluating training programs Ed. ke-3. San Francisco: Berret-Koehler Publishers, Inc. 2005 